Pinneira, 1974; K Merton. Robert. Puritanism, Pietism and Sicience. In Barber, B., \& Hirsch, W. eds. The sociology of science. New York, The Free Press, 1962; Parsons, Talcott. The institutionalization of scientific investigation. In ibid, Weber, Max. A ética protestante e o espirito do capitalismo. Rıo de Janeiro, Editora Zahar, 1967; e Weber, Max. O político e o cientista. Lisboa, Ed. Presença, s/d.

2 A esse respeito, dentre outros: Bourdieu, Pierre. A economia das trocas simbólicas. São Paulo, Eư. Perspectiva, 1974; Bourdieu, Pierre. Campo intelectual e projeto criador. In Pouillon, Jean et alii. Problemas do estruturalismo. Rio de Janeiro, Ed. Zahar, 1968; Gianotti, J.A. Ciência para o desenvolvimento; $O$ contexto e os intelectuais, In Exercícios de filosofia. Seleçōes CEBRAP, São Paulo, Ed. Brasiliense, 1975; Gianotti, J.A. Burocratas da cultura. Opinião, 21 mar. 1975, p. 20.

3 Tal proposição está claramente definida na p. 97 do livro em questão.

${ }^{4}$ Pelo menos em alguns momentos, a descrição feita da movimentaçăo que cercou a erradicação da febre amarela e a campanha de vacinação obrigatória contra a variola - "o primeiro embate sério entre ciência e sociedade" (p. 66) - nos conduz a essa interpretação

\section{Operário, operária}

Por Arakcy Martins Rodrigues. São Paulo, Símbolo, 1978, 144p

O livro de Arakcy Martins Rodrigues motivou-me já a partir da capa azul, do título não-acadêmico, Operário, operária, de uma produção acadêmica e da epígrafe, extraída da canção Vai trabalhar, vagabundo; li suas quase 150 páginas num só fôlego.

O leitor, após passar os olhos neste nariz de cera elogioso, naturalmente deverá estar-se perguntando o que, além desses traços formais, me atraiu. $E$ é isso que pretendo detalhar na seqüência da presente resenha.

A. M. Rodrigues realiza um trabalho que, sem receio, pode-se classificar de multidisciplinar. LIcenciada em filosofia pela Universidade de São Paulo, empreendeu, posteriormente, sua formação psicanalítica, ao mesmo tempo em que foi desenvolvendo ampla experiência como. pesquisadora em instituições públicas e privadas; cursou, a nivel de pós-graduação, algumas cadeiras de estatística ria Faculdade de Saúde Pública da USP. Toda essa atividade profissional, conforme salienta Sérgio Miceli nà apresentação, muniu-a de um seguro domínio dos procedimentos quantitativos. Contudo, acabou optando, na pesquisa que compõe Operário, operária, pela técnica 'da entrevista aberta, adotando-a de maneira inovadora.

Afirma na introdução que seu trabalho "... é uma tentativa de levantar algumas hipóteses que aju- dem na compreensão do comportamento da mulher em relação ao trabalho, dentro de uma categoria socioprofissional loperariado industrial)" (p. 17). E o subtítulo (acadêmico), neste sentido, é bastante elucidativo: Estudo exploratório sobre o operariado industrial da Grande São Paulo.

O estudo apresenta os resultados da análise de 20 entrevistas abertas (com 6 homens e $14 \mathrm{mu}$ Iheres) realizadas durante $o$ segundo semestre de 1975 e o primeiro de 1976 nos seguintes bairros, subdistritos e distritos da Grande São Paulo: São Caetano, Morumbi, Parque Bristol, São Bernardo, Cajamar, Jardim Palmeira, Vila Maria, Vila Élida, M'Boi Mirim, Jardim da Saúde, Peri-Peri, Casa Verde Alta, Pedreira, Vila Sônia, Campo Limpo, Diadema e Jardim Abril (p. 58-9). "Embora o foco de interesse fosse o comportamento da mulher em relação ao trabalho dentro de uma categoria socioprofissional" , salienta Arakcy que "a inexistência entre nós de pesquisas nesses moldes, sobre operários; nos levou a incluir homens na amostra, a fim de viabilizar as comparações"

Adotou-se como definição de trabalho, o trabalho doméstico e o trabalho remunerado feito em casa, ${ }^{\prime}{ }^{\prime} .$. donde a inclusão de mulheres que não trabalham remuneradamente (mulheres de operários) e de mulheres que exercem atividades remuneradas em casa". E, finalmente, a categoria socioprofissional "operário industrial" foi definida a partir do tipo de trabalho realizado dentro da indústria, incluindo-se entre os entrevistados apenas os que se vinculassem à atividade produtiva. E o grupo estudado foi subdividido entre operários qualificados, semiqualificados e não-qualıficados (p. 58)

Após esta sucinta exposicão sobre a amostra da investigação, pretendo tecer algumas considerações a respeito da metodologia adotada na pesquisa. Arakcy $M$. Rodrigues enfatiza que se propôs "... a estudar o comportamento da mulher operária em relação ao trabalho, partindo da tarefa básica de investigar como o individuo processa enquanto tal os determinis- 
mos sociais" (p. 20-1, em destaque no original)

Partindo da idéia segundo a qual as experiências vividas e conhecidas pelo indivíduo - ou o grau de complexidade dessas experiências - determinam a organização do espaço psicológico ou seu grau de complexidade cognitiva, pode-se pensar que o indivíduo vivenciará tais experiências vinculado, numa sociedade estratificada como a nossa, a classes sociais ou a frações de classe. À concepção acima esboçada, a autora acresce uma das idéias-chave da teoria sociológica de Pierre Bourdieu, qual seja, a do habitus: "o pressuposto de que as condições externas, objetivas, são internalizadas pelos indivíduos, e que através do comportamento a interioridade volta a se fazer exterioridade ..." (p. 23). Ainda mais: "determinadas configurações, certas formas de estruturação dos conteúdos internalizados, são gerados a partir da vivência, historicamente dada dentro de cada grupo social, das mesmas condições objetivas de existência" (p. 23). Assim, se para Bourdieu as condições de existência geram historicamente dentro de cada classe social um habitus que estrutura e dá sentido ao conjunto de representações e práticas, a pesquisadora desenvolve a idéia de que "... pelo mesmo tipo de mecanismo ... vamos encontrar, dentro de cada classe, duas vertentes básicas gerando a variante masculina e feminina do habitus" (p. 24).

A partir daí, sua proposta de trabatho se direciona no sentido de estudar o tipo de determinação impresso pelas condiç̃es socioeconômicas nos indivíduos, "... distinguindo o sexo como mais uma determinação que, sem agir direta- mente, é da mesma forma retradu'zida numa ordem cultural". E julga ser necessário apontar por meio de que mecanismos foi gerada historicamente a opressão de classes ou de um sexo sobre outro, bem como enxergar "de que forma a internalização, por parte dos 'oprimidos', das condições dadas, contribui ao invés de negar a preservação do status quo ..." (p. 24).
Dessa maneira, pela própria natureza de suas preocupações, nota-se que Arakcy abdicou na pesquisa de qualquer pretensão quantitativa, uma vez que, se se prendesse aos procedimentos mais correntes em investigação social, correria o (sério) risco de ganhar em rigor e perder o objeto. Sem se curvar ao que Bourdieu denominou fetichismo da estatística lque "conduz alguns a não considerar digno de ser conhecido aquilo que não pode ser medido, em vez de tentar medir aquilo que merece ser conhecido ou de recorrer, para estudá-10, a métodos aparentemente menos rigorosos") e sem se utilizar do questionário como instrumentos para detectar opiniões e explicações (pois conduz o entrevistado a assumir uma posição normativa e a emitir uma frase de alto nivel e/ou um chavãol a auto$\mathrm{ra}$, em 20 entrevistas abertas, detectou alguns dos princípios que norteiam as representações que os trabalhadores possuem sobre seu passado, sua família, seu trabalho, uso do corpo, tempo e dinheiro.

O exíguo espaço desta resenha não permite um maior aprofundamento de várias questôes que o trabalho levanta, bem como a apresentação de algumas de suas conclusões. Apenas a título de indicação, saliento que a leitura da segunda parte, Análise do material, em especial, os capítulos II e III - respectivamente as experiências de vida e Os recursos presentes na explicação do mundo - é bastante facilitada pelo rico conteúdo dos depoimentos e pela forma como o material é montado. Um dos trechos mais fascinantes, de fato, concentra-se no exame do que a autora chama de sistema de doações. Como salienta Sérgio Miceli na apresentação, por este sistema "... certos membros da família operária desistem de 'si mesmos' contentando-se em viver por procuração as 'façanhas' de outros que só aparecem enquanto tais porque absorvem o trabalho e os investimentos de todos" ( $p$. 14).

Assim, integrando várias concepções de P. Bourdieu, L. X. Bol- tanski, E. Goffman, R. Hoggart, E. Durhan, E. Jelin, K. Lewin, $P$. Spinky e G. A. Kelly, entre outros, na análise do material coletado, o trabalho de Arakcy Martins Rodrigues ganha (e muito) em qualidade $\mathrm{e}$ interpretação o que, eventualmente, possa ter perdido em precisão. Isento de modismos ou dialetos, o que se lê é, efetivamente, uma aula de método. E que aula!

Afrânio Mendes Catani 